\title{
Importance of mitochondrial superoxide dismutase expression in insulin-producing cells for the toxicity of reactive oxygen species and proinflammatory cytokines
}

Received: 20 December 2004 / Accepted: 20 March 2005 / Published online: 29 June 2005

(C) Springer-Verlag 2005

\begin{abstract}
Aims/hypothesis: Free radicals generated in mitochondria play a crucial role in the toxic effects of cytokines upon insulin-producing cells. This study therefore investigated the role of manganese superoxide dismutase (MnSOD) in cytokine-mediated toxicity in insulin-producing cells. Methods: MnSOD was either stably overexpressed (MnSODsense) or stably suppressed (MnSODantisense) in insulin-producing RINm5F cells. Cell viability was quantified after incubation with different chemical reactive oxygen species (ROS) generators and with cytokines (IL-1 $\beta$ alone or a mixture of IL- $1 \beta$, TNF- $\alpha$ and IFN- $\gamma$ ). Additionally, cell proliferation and endogenous MnSOD protein expression were determined after exposure to cytokines. Results: After incubation with hydrogen peroxide $\left(\mathrm{H}_{2} \mathrm{O}_{2}\right)$ or hypoxanthine/xanthine oxidase no significant differences were observed in viability between control and MnSOD sense or MnSODantisense clones. MnSOD overexpression reduced the viability of MnSODsense cells after exposure to the intracellular ROS generator menadione compared with control and MnSODantisense cells. MnSODsense cells also showed the highest susceptibility to cytokine toxicity with more than $75 \%$ loss of viability and a significant reduction of the proliferation rate after $72 \mathrm{~h}$ of incubation with a cytokine mixture. In comparison with control cells (67\% viability loss), the reduction of viability in MnSODantisense cells was lower (50\%), indicating a sensitising role of MnSOD in the progression of cytokine toxicity. The
\end{abstract}

S. Lortz $\cdot$ E. Gurgul-Convey $\cdot$ S. Lenzen $\cdot$ M. Tiedge

Institute of Clinical Biochemistry,

Hanover Medical School,

Hanover, Germany

M. Tiedge $(\bowtie)$

Institute of Medical Biochemistry

and Molecular Biology,

University of Rostock,

Schillingallee 70 ,

18057 Rostock, Germany

e-mail: markus.tiedge@med.uni-rostock.de

Tel.: +49-381-4945751

Fax: +49-381-4945752 cell proliferation rate decreased in parallel to the reduction of cell viability. The MnSOD expression level after exposure to cytokines was also significantly lower in $\mathrm{Mn}$ SODantisense cells than in control or MnSODsense cells. Conclusions/interpretation: The increase of the mitochondrial imbalance between the superoxide- and the $\mathrm{H}_{2} \mathrm{O}_{2}$ inactivating enzyme activities corresponds with a greater susceptibility to cytokines. Thus optimal antioxidative strategies to protect insulin-producing cells against cytokine toxicity may comprise a combined overexpression of $\mathrm{H}_{2} \mathrm{O}_{2}-$ inactivating enzymes or suppression of MnSOD activity.

Keywords Diabetes mellitus - Insulin-producing cells · Mitochondrion - Reactive oxygen species - Superoxide dismutase

Abbreviations BrdU: 5-bromo-2-deoxyuridine . CuZnSOD: copper/zinc superoxide dismutase - G418: geneticin - GPx: glutathione peroxidase $\cdot \mathrm{H}_{2} \mathrm{O}_{2}$ : hydrogen peroxide $\cdot \mathrm{HX}$ : hypoxanthine $\cdot$ MnSOD: manganese superoxide dismutase $\cdot$ MTT: 3-(4,5-dimethylthiazol-2-yl)2,5-diphenyl tetrazolium bromide $\cdot \mathrm{NF}-\mathrm{kB}$ : nuclear factor kappa B · NO: nitric oxide - ROS: reactive oxygen species · SOD: superoxide dismutase $\cdot \mathrm{XO}$ : xanthine oxidase

\section{Introduction}

The function of superoxide dismutase (SOD) as an antioxidant enzyme has been widely accepted [1]. Nevertheless, there is also experimental evidence that, under certain circumstances, high SOD enzyme activities may promote toxicity of superoxide-radical-forming compounds (for review, see [2]).

The increased toxicity of a variety of superoxide-radicalforming compounds observed in a number of cell types overexpressing SOD [3-5] has been considered to result from elevated hydrogen peroxide $\left(\mathrm{H}_{2} \mathrm{O}_{2}\right)$ concentrations and subsequent oxidative damage following hydroxyl radical generation $[6,7]$. This enhanced toxicity is likely to become evident in particular when the capacity for en- 
zymatic inactivation of $\mathrm{H}_{2} \mathrm{O}_{2}$ is limited, such as is the case in insulin-producing cells $[8,9]$.

In recent studies we could show that mitochondrially derived radicals play a crucial role in cytokine toxicity in insulin-producing cells. In particular the mitochondrial targeting of catalase proved to be an efficient strategy to protect the cells against cytokine-mediated cell death, acting against the imbalance between superoxide dismutation and the inactivation of $\mathrm{H}_{2} \mathrm{O}_{2}$ [10]. Also manganese SOD (MnSOD) overexpression proved to be an efficient principle to ameliorate the activation of nuclear factor kappa $\mathrm{B}$ $(\mathrm{NF}-\mathrm{KB})$ and inducible nitric oxide (NO) synthase after cytokine exposure in insulin-producing RINm5F cells in the early phase of cytokine signalling [11]. In the light of these data the role of MnSOD in the toxicity of reactive oxygen species (ROS) and cytokines deserves specific consideration, as various studies in different cell types have reported a higher susceptibility to ROS rather than a protection [3-5]. This raises the question about the functional role of MnSOD in insulin-producing cells under the physiological situation of low-activity levels of $\mathrm{H}_{2} \mathrm{O}_{2}$-inactivating enzymes.

The intramitochondrial production of superoxide radicals in the absence of relevant consumption processes such as by biomolecules (e.g. NO) will result in an increase of $\mathrm{H}_{2} \mathrm{O}_{2}$ concentrations [12]. On the other hand, it has been suggested [13] that because dismutation competes with reactions that convert superoxide radicals into $\mathrm{H}_{2} \mathrm{O}_{2}$ at higher yields, SOD overexpression should also reduce the generation of $\mathrm{H}_{2} \mathrm{O}_{2}$. However, because in most cell types superoxide-inactivating capacity is higher than the $\mathrm{H}_{2} \mathrm{O}_{2}$ inactivating capacity (ratio $>1$ ), the consequence of high SOD activity is an increase of $\mathrm{H}_{2} \mathrm{O}_{2}$ production. Only in the rarer situation of a ratio lower than unity should the rate of $\mathrm{H}_{2} \mathrm{O}_{2}$ generation be slightly decreased in parallel with increasing SOD activity (for review, see [2]). This explains why MnSOD may be protective as well as harmful, depending upon the conditions of ROS generation inside the cell.

In this study we have investigated the effects of MnSOD overexpression or suppression for the toxicity of chemical generators of superoxide radicals and $\mathrm{H}_{2} \mathrm{O}_{2}$ as well as proinflammatory cytokines on insulin-producing cells. For this purpose we have used insulin-producing RINm5F cells, which do not differ from primary beta cells in their enzymatic antioxidative defence status.

\section{Materials and methods}

Materials Restriction enzymes and T4 DNA ligase were obtained from New England Biolabs (Beverly, MA, USA). Hypoxanthine (HX), xanthine oxidase (XO), menadione (2-methyl-1,4-naphthoquinone) and MTT (3-[4,5-dimethylthiazol-2-yl]-2,5-diphenyl tetrazolium bromide) were purchased from Sigma (St Louis, MO, USA). Menadione was recrystallised from methanol before use. The pcDNA3 expression vector, geneticin (G418) and all other tissue culture equipment were from Invitrogen (Karlsruhe, Germany).
The cDNA coding for human MnSOD was kindly provided by Dr G. I. Bell (Chicago, IL, USA) and the antibody against MnSOD was a kind gift from Dr M. D. Asayama (Kitakyushu, Japan).

RINm5F cell culture and overexpression of antioxidant enzymes in RINm5F cells RINm5F tissue culture cells (passage 65-75) were cultured as described [9] in RPMI 1640 medium, supplemented with $10 \mathrm{mmol} / \mathrm{l}$ glucose, $10 \%(\mathrm{v} / \mathrm{v})$ fetal calf serum, penicillin and streptomycin in a humidified atmosphere at $37^{\circ} \mathrm{C}$ and $5 \% \mathrm{CO}_{2}$. Insulinproducing RINm5F cells have an antioxidative defence status with an antioxidant enzyme equipment which does not differ from primary islet cells $[9,14]$.

The cDNA for human mitochondrial MnSOD [15] was subcloned into the pcDNA3 expression vector in sense (MnSODsense) or antisense orientation (MnSODantisense) by standard molecular biology techniques [11]. RINm5F cells were stably transfected with the vector and positive clones were selected through resistance against G418 (250 $\mu \mathrm{g} / \mathrm{ml})$. All clones were verified for MnSOD expression at the level of mRNA and protein as well as at the level of enzyme activities, as described before [11]. To study extreme situations of MnSOD activities we used in addition to a control clone two cell clones: (1) the MnSODsense clone with a $120 \%$ increase of MnSOD protein expresion; and (2) the MnSODantisense clone with a $40 \%$ decrease of MnSOD protein expression (Fig. 3). The transfection of RINm5F cells with the pcDNA3 vector lacking insert (control cells) affected neither the expression of MnSOD nor the expression of the other cytoprotective enzymes. Notably the overexpression or suppression of MnSOD also did not affect the expression of other antioxidant enzymes, in particular those of catalase and glutathione peroxidase (GPx). The antioxidant enzyme activities in the cell clones used were as follows (U/mg protein): control cells, catalase: $6 \pm 1$, GPx: $0.17 \pm 0.03$, copper/zinc superoxide dismutase (CuZnSOD): 70 \pm 7, MnSOD: 13 \pm 2; MnSODsense cells, catalase: $5 \pm 1$, GPx: $0.14 \pm 0.02$, CuZnSOD: 68 \pm , MnSOD: 31 \pm ; MnSODantisense cells: catalase: $7 \pm 1$, GPx: $0.13 \pm 0.01, \mathrm{CuZnSOD}: 53 \pm 5$, MnSOD: $3 \pm 1$. The insulin content (ng/ $\mu \mathrm{g}$ DNA) was as follows in the control and MnSODantisense and MnSOD sense RINm5F cell clones: control, $3.8 \pm 0.3$; MnSODantisense, $3.3 \pm 0.3 ;$ MnSODsense, $3.4 \pm 0.2$. The data are given as means \pm SEM from four individual experiments.

Exposure to ROS donors Control and transfected RINm5F cells were seeded at a concentration of $5 \times 10^{4}$ cells/well in $100-\mu \mathrm{l}$ culture medium in 96 -well microplates $24 \mathrm{~h}$ before they were incubated with the test compounds. The cells were exposed to $50 \mu \mathrm{mol} / 1 \mathrm{H}_{2} \mathrm{O}_{2}$ for $2 \mathrm{~h}$ in HEPES (20 mmol/l)-supplemented Krebs-Ringer bicarbonate medium with $5 \mathrm{mmol} / \mathrm{l}$ glucose and, after removal of $\mathrm{H}_{2} \mathrm{O}_{2}$, for another $18 \mathrm{~h}$ in RPMI 1640 medium. In another experimental protocol, cells were incubated with a mixture of 125 $\mu \mathrm{mol} / \mathrm{l} \mathrm{HX}$ and $2.5 \mathrm{mU} / \mathrm{ml}$ XO in RPMI 1640 medium for $18 \mathrm{~h}$ as described before [14]. This system continuously generates superoxide radicals and $\mathrm{H}_{2} \mathrm{O}_{2}$ through 
electron transversion from the substrate $\mathrm{HX}$ [16]. At a $\mathrm{pH}$ of 7.4 the portion of superoxide radical formation has been described as being in the range of $30 \%$ [17]. $\mathrm{H}_{2} \mathrm{O}_{2}$ accumulated in the culture medium depending on the HX concentration, reaching a saturation level $3 \mathrm{~h}$ after initiation of the $\mathrm{HX} / \mathrm{XO}$ reaction. Menadione was freshly dissolved and cells were exposed at a final concentration of $15 \mu \mathrm{mol} / \mathrm{l}$ in RPMI 1640 medium for $18 \mathrm{~h}$ as described before [14].

Exposure to cytokines Control and transfected RINm5F cells were seeded at a density of 5,000 cells/well in $100-\mu 1$ culture medium in 96-well microplates and allowed to attach for $24 \mathrm{~h}$ before $600 \mathrm{U} / \mathrm{ml}$ human IL-1 $\beta$ (PromoCell, Heidelberg, Germany) or a combination of cytokines $(0.5 \times$ cytokine mixture or $1 \times$ cytokine mixture $)$ was added for a 72 -h time period. The $1 \times$ cytokine mixture consisted of $60 \mathrm{U} / \mathrm{ml} \mathrm{IL}-1 \beta, 185 \mathrm{U} / \mathrm{ml}$ human TNF- $\alpha$ and $14 \mathrm{U} / \mathrm{ml}$ rat IFN- $\gamma$ (PromoCell). The $0.5 \times$ cytokine mixture consisted of half of these concentrations.

MTT viability assay After exposure to the different toxins, the viability of the cells was determined using a microtitreplate-based MTT assay [18]. The decrease of MTT activity represents a reliable metabolically based test for quantification of cell viability which correlates well with a loss of RINm5F cell viability in the lactate dehydrogenase release assay and in differential staining with fluorescent dyes $[9,19]$. The sense and antisense expression of MnSOD did not affect the absolute levels of dehydrogenase activities in the MTT assay and the cell growth rate in comparison with mock-transfected control cells in the absence of the test compounds.

Determination of cell integrity and viability by differential staining RINm5F cells were stained using the DNA-binding dyes Hoechst 33342 (Molecular Probes, Eugene, OR, USA) and propidium iodide (Sigma) as indices of the number of viable, necrotic and apoptotic cells, as described previously [20].

Measurement of cell proliferation The proliferation rate of RINm5F cells was quantified by the colorimetric 5-bromo2-deoxyuridine (BrdU) Cell Proliferation ELISA (Roche Molecular Biochemicals, Mannheim, Germany). Data were expressed as a percentage of untreated cells after different periods of cytokine exposure. The absolute $A_{492 \mathrm{~nm}}$ absorbance rates of the RINm5F control cells and the stably transfected cell clones were not significantly different, indicating comparable proliferation rates under control conditions.

Western blot analyses of MnSOD protein expression Whole cell extracts were obtained through sonification in ice-cold PBS on ice for $15 \mathrm{~s}$ at $60 \mathrm{~W}$ with a BraunSonic 125 sonifier. Protein content was determined by the BCA assay (Pierce, Rockford, IL, USA). Twenty micrograms of protein were fractionated by SDS-PAGE and transferred to polyvinylidene fluoride membranes. Nonspecific binding sites of the membranes were blocked by non-fat dry milk overnight at $4^{\circ} \mathrm{C}$. Then the blots were incubated with a specific primary antibody against rat MnSOD at a dilution of 1:10,000 for $1 \mathrm{~h}$ at room temperature, followed by a 1-h incubation period with the secondary antibody, peroxidase-conjugated AffiniPure donkey antirabbit $\operatorname{IgG}(\mathrm{H}+\mathrm{L})$ from Dianova (Hamburg, Germany), at a dilution of $1: 15,000$ at room temperature. The protein bands were visualised by chemiluminescence using the ECL detection system (Amersham Bioscience, Freiburg, Germany). The intensity of the bands was quantified through densitometry with the Gel-Pro Analyzer 4.0 program (Media Cybernetics, Silver Spring, MD, USA). Equal loading of lanes was verified by Ponceau staining of the blots (data not shown).

Statistical analyses Data are expressed as means \pm SEM. Statistical analyses were performed using ANOVA plus Dunnett's test for multiple comparisons. Unless mentioned otherwise, a $p$ value $<0.05$ was regarded as statistically significant. Statistical analyses and non-linear regression analyses of the curves were done by the Prism analysis program (Graphpad, San Diego, CA, USA).

\section{Results}

It was the aim of this study to clarify the role of MnSOD in the toxicity of free-radical-generating compounds and cytokines. For this purpose we generated insulin-producing RINm5F cell clones with high or low MnSOD enzyme activities through expression of sense or antisense constructs. Neither the overexpression nor the suppression of MnSOD significantly affected the expression of the other antioxidant enzymes, in particular the activity of catalase and GPx, and the insulin content of the used cell clones, thus excluding effects of clonal variations during the selection process of cell clones.

Toxicity of $\mathrm{H}_{2} \mathrm{O}_{2}, \mathrm{HX} / \mathrm{XO}$ and menadione in MnSODsense and MnSODantisense insulin-producing RINm5F cells The first characterisation of the two MnSOD-manipulated insulin-producing RINm5F cell clones (MnSODsense and MnSODantisense) was performed using the three wellcharacterized and defined chemical generators of ROS: $\mathrm{H}_{2} \mathrm{O}_{2}$, the $\mathrm{HX} / \mathrm{XO}$ system and menadione.

The viability of control RINm5F cells was reduced to $65 \%$ through incubation with $50 \mu \mathrm{mol} / 1 \mathrm{H}_{2} \mathrm{O}_{2}$ as evident from the MTT assay (Table 1). Neither overexpression of MnSOD (MnSODsense) nor suppression of MnSOD (MnSODantisense) significantly affected the $\mathrm{H}_{2} \mathrm{O}_{2}$-induced reduction of viability (Table 1 ).

After incubation with HX/XO (HX:125 $\mu \mathrm{mol} / \mathrm{l} ; \mathrm{HO}: 2.5$ $\mathrm{mU} / \mathrm{ml}$ ), a system which continuously generates $\mathrm{H}_{2} \mathrm{O}_{2}$ and superoxide radicals extracellularly, control RINm5F cells exhibited a remaining viability of $61 \%$. As in the case of the incubation with $\mathrm{H}_{2} \mathrm{O}_{2}$, neither overexpression of MnSOD 
Table 1 Effects of MnSODsense and antisense transfection of insulin-producing RINm5F cells on cell viability measured by the MTT assay after exposure to the ROS generators hydrogen peroxide $\left(\mathrm{H}_{2} \mathrm{O}_{2}\right)$, hypoxanthine/xanthine oxidase $(\mathrm{HX} / \mathrm{XO})$ or menadione

\begin{tabular}{llll}
\hline Test agent & MnSODantisense & Control & MnSODsense \\
\hline $\mathrm{H}_{2} \mathrm{O}_{2}(50 \mu \mathrm{mol} / \mathrm{l})$ & $61 \pm 7(6)$ & $65 \pm 2(4)$ & $66 \pm 4(6)$ \\
$\mathrm{HX} / \mathrm{XO}(125 \mu \mathrm{mol} / \mathrm{l} / 2.5 \mathrm{mU} / \mathrm{ml})$ & $63 \pm 6(5)$ & $61 \pm 3(3)$ & $60 \pm 5(5)$ \\
Menadione $(15 \mu \mathrm{mol} / \mathrm{l})$ & $38 \pm 8(4)$ & $41 \pm 9(4)$ & $13 \pm 5^{*}(4)$ \\
\hline
\end{tabular}

Viability values (means \pm SEM with the number of experiments in parentheses) were calculated from the absolute absorbance rates and are a percentage of the untreated cells

${ }^{*} p<0.05$ compared with control cells (ANOVA/Dunnett's test for multiple comparisons)

(MnSODsense) nor suppression of MnSOD (MnSODantisense) significantly affected the $\mathrm{HX} / \mathrm{XO}$-induced reduction of viability (Table 1).

Exposure to $15 \mu \mathrm{mol} / \mathrm{l}$ menadione reduced the viability of RINm5F control cells to $41 \%$ (Table 1). Suppression of MnSOD (MnSODantisense) did not change menadione toxicity significantly, but in cells overexpressing MnSOD (MnSODsense) the viability was significantly reduced to $13 \%$ after exposure to menadione (Table 1).

Toxicity of cytokines in MnSODsense and MnSODantisense insulin-producing RINm5F cells The viability of control and transfected RINm5F cells was reduced after a 72-h incubation with IL-1 $\beta$ in a concentration-dependent manner (Fig. 1). IL-1 $\beta$ at $60 \mathrm{U} / \mathrm{ml}$ caused in the MTT assay only a minor decrease of the viability of less than $10 \%$ in non-transfected and in MnSODantisense-transfected cells (Fig. 1). Overexpression of MnSOD resulted in a significantly $(p<0.05)$ greater viability reduction to $68 \%$ after incubation with $60 \mathrm{U} / \mathrm{ml} \mathrm{IL-1 \beta}$ (Fig. 1).

Higher IL-1 $\beta$ concentrations of 300 and $600 \mathrm{U} / \mathrm{ml}$ decreased the viability in control cells by around $15-25 \%$ (Fig. 1). Again, the extent of viability reduction by these higher IL-1 $\beta$ concentrations was not significantly greater than in MnSODantisense cells (Fig. 1). However, the reduction of viability was significantly $(p<0.05)$ more pronounced in MnSODsense cells incubated with either 300 or $600 \mathrm{U} / \mathrm{ml} \mathrm{IL-1 \beta}$ when compared with MnSODantisense cells (Fig. 1).

The more toxic cytokine mixture, consisting of the proinflammatory beta-cell-toxic cytokines IL- $1 \beta$, TNF- $\alpha$ and IFN- $\gamma(60 \mathrm{U} / \mathrm{ml} \mathrm{IL}-1 \beta, 185 \mathrm{U} / \mathrm{ml}$ TNF- $\alpha, 14 \mathrm{U} / \mathrm{ml}$ IFN- $\gamma$ ), caused a more pronounced decrease of viability than IL-1 $\beta$ alone (Fig. 1). At both a higher $(1 \times$ cytokine mixture) and lower $(0.5 \times$ cytokine mixture $)$ concentration the reduction of viability was significantly $(p<0.05)$ greaterin MnSODsense cells than in MnSODantisense cells (Fig. 1), although no significant differences between control and MnSODsense cells could be determined.

The data of the MTT assay corresponded well with the cell death rate examined by differential staining of the cells in response to cytokines. The cell death rate after 72$\mathrm{h}$ exposure to the $1 \times$ cytokine mixture was $60.5 \pm 8.3 \%$ for the control cells, $85.7 \pm 7.2 \%$ for the MnSODsense cells and $31.4 \pm 2.2 \%$ for the MnSODantisense cells ( $n=4$ independent experiments; $p<0.05$ MnSODsense and MnSOD antisense cells compared with control cells).
Effects of cytokines on the proliferation rate of MnSOD sense and MnSODantisense insulin-producing RINm5F cells From previous studies it was evident that the cell growth rate of RINm5F cells was significantly affected by cytokines and thus represents another valid parameter of
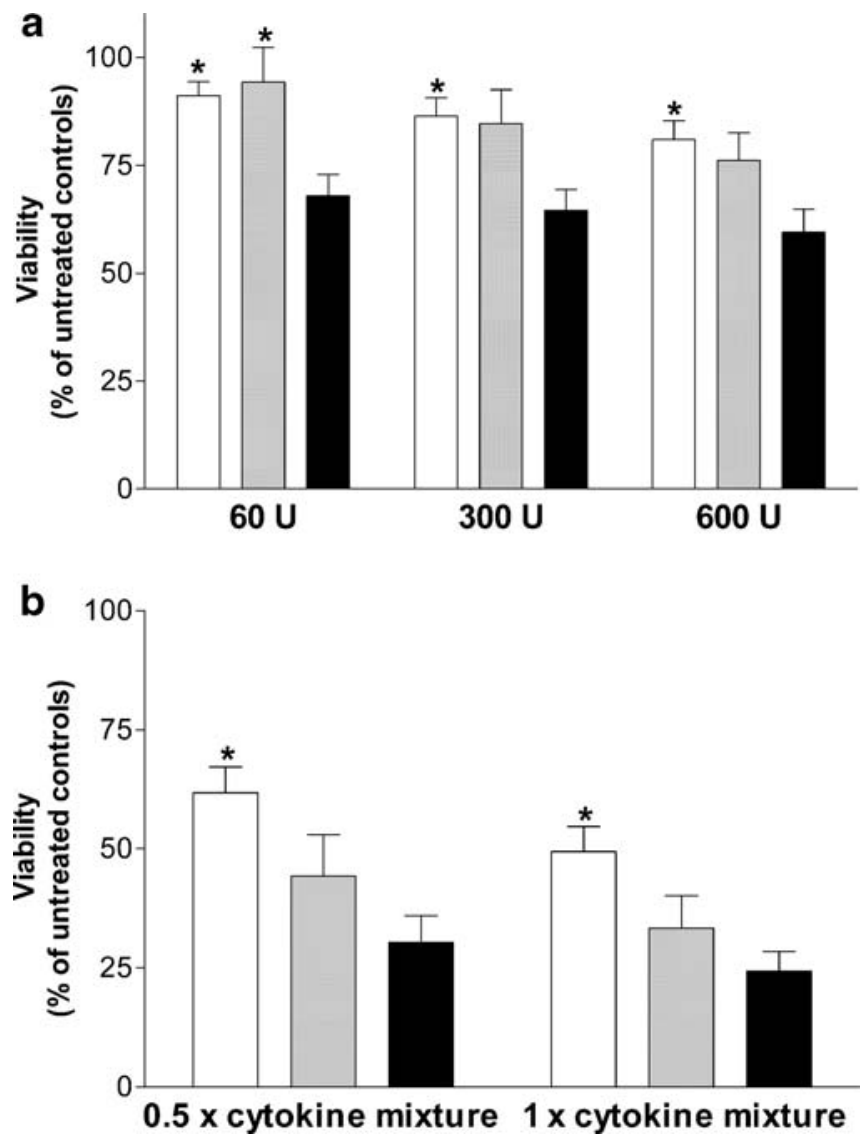

Fig. 1 Effects of MnSODsense and antisense transfection of insulin-producing RINm5F cells on cell viability after exposure to IL-1 $\beta$ alone (a) or to a cytokine mixture (b). Open bars RINm5FMnSODantisense cells; grey bars RINm5F control cells; black bars RINm5F-MnSODsense cells. Control and transfected insulin-producing RINm5F cells were incubated for $72 \mathrm{~h}$ with IL-1 $\beta(60-600$ $\mathrm{U} / \mathrm{ml})$ alone or with a cytokine mixture $(1 \times$ cytokine mixture: $60 \mathrm{U} /$ $\mathrm{ml}$ IL-1 $\beta, 185 \mathrm{U} / \mathrm{ml}$ TNF- $\alpha, 14 \mathrm{U} / \mathrm{ml}$ IFN- $\gamma)$ or half of it $(0.5 \times$ cytokine mixture). Cell viability was determined by the MTT assay and expressed as a percentage of the untreated cells. Data are means \pm SEM from four individual experiments. ${ }^{*} p<0.05$, compared with MnSODsense cells (ANOVA/Dunnett's test for multiple comparisons) 
the toxic effects of cytokines [14, 19, 21]. Therefore, in addition to the viability loss observed in the MTT assay, the proliferation rate of the different cell clones after incubation with IL-1 $\beta$ and with the cytokine mixture was quantified.

Both IL- $1 \beta$ and the cytokine mixture reduced the proliferation rate at different time points $(24,48,72 \mathrm{~h})$ during the incubation. The reduction of the proliferation rate after exposure to IL-1 $\beta(600 \mathrm{U} / \mathrm{ml})$ was significantly $(p<0.05)$ greater in MnSODsense cells than in MnSODantisense cells (Fig. 2). After incubation with the cytokine mixture $(60 \mathrm{U} / \mathrm{ml} \mathrm{IL}-1 \beta, 185 \mathrm{U} / \mathrm{ml}$ TNF- $\alpha, 14 \mathrm{U} / \mathrm{ml} \mathrm{IFN}-\gamma)$ the reduction of the proliferation rate was more pronounced than in the case of IL- $1 \beta$ alone and significantly $(p<0.05)$
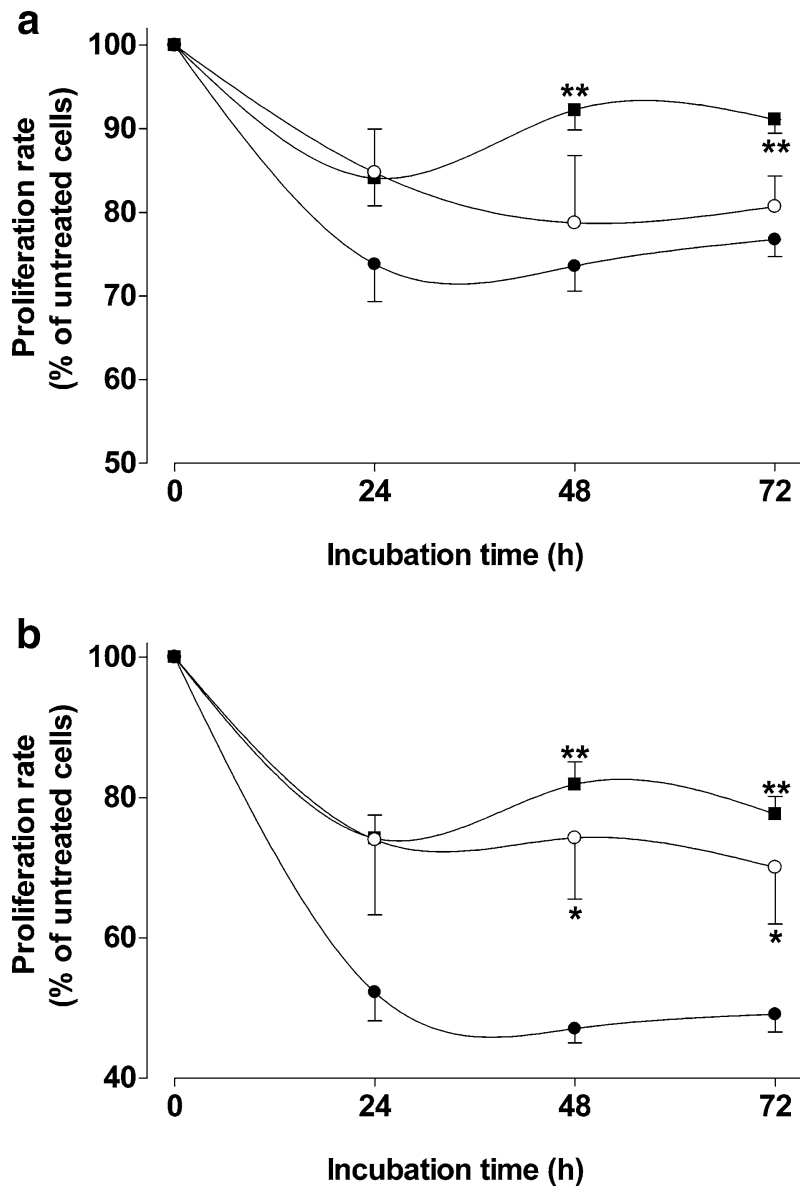

Fig. 2 Effects of MnSODsense and antisense transfection of insulin-producing RINm5F cells on the proliferation rate after cytokine treatment. Open circles RINm5F control cells; solid circles RINm5F-MnSODsense cells; solid squares RINm5F-MnSODantisense cells. Cells were exposed to IL-1 $\beta$ alone $(600 \mathrm{U} / \mathrm{ml})$ (a) or $1 \times$ cytokine mixture $(60 \mathrm{U} / \mathrm{ml} \mathrm{IL}-1 \beta, 185 \mathrm{U} / \mathrm{ml} \mathrm{TNF}-\alpha, 14 \mathrm{U} / \mathrm{ml}$ IFN- $\gamma$ ) (b) for 24,48 or $72 \mathrm{~h}$. Proliferation was quantified by a BrdU-specific ELISA and expressed as a percentage of the proliferation rate of cells without cytokine treatment. Absolute absorbance rates of the three RINm5F clones were not significantly different (data not presented). Shown are means \pm SEM from four to six individual experiments. $* p<0.05, * * p<0.01$ compared with MnSODsense cells (ANOVA/Dunnett's test for multiple comparisons) a
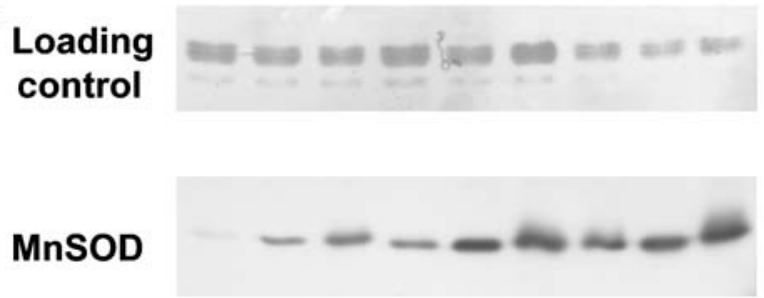

b

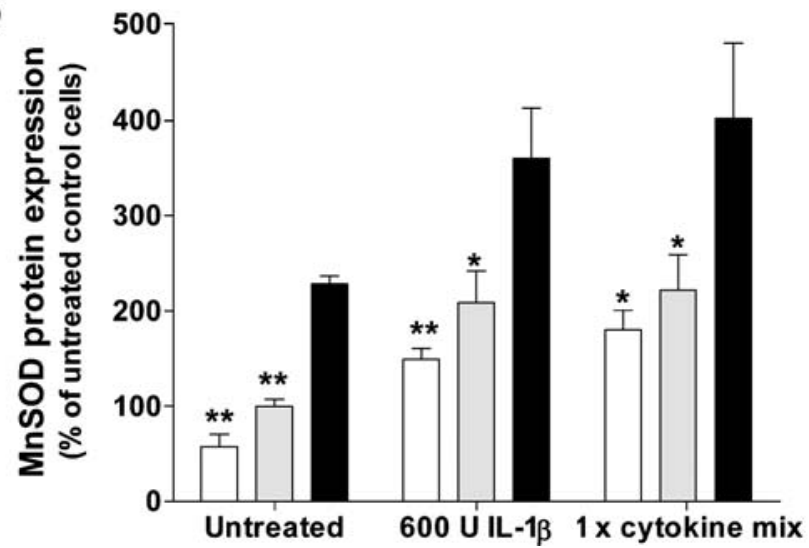

Fig. 3 Effects of cytokine treatment on MnSOD protein expression in MnSODsense- and antisense-transfected insulin-producing RINm5F cells. Cells were seeded $24 \mathrm{~h}$ before incubation with IL-1 $\beta$ alone $(600 \mathrm{U} / \mathrm{ml})$ or with the $1 \times$ cytokine mixture $(60 \mathrm{U} / \mathrm{ml} \mathrm{IL}-1 \beta, 185$ $\mathrm{U} / \mathrm{ml}$ TNF- $\alpha, 14 \mathrm{U} / \mathrm{ml}$ IFN- $\gamma$ ). Twenty-four hours after incubation, the cells were lysed and MnSOD protein expression was quantified by Western blot analysis. A Ponceau-stained section of the membrane for loading control purposes, and a representative blot from six individual experiments (a). Quantitative densitometric analysis of six experiments (b). Open bars RINm5F-MnSODantisense cells; grey bars RINm5F control cells; black bars RINm5FMnSODsense cells. Band intensities from control cells were set at $100 \%$. Data are means \pm SEM. ${ }^{*} p<0.05, * * p<0.01$, compared with MnSODsense cells (ANOVA/Dunnett's test for multiple comparisons)

greater in both MnSODsense and control cells than in MnSODantisense cells (Fig. 2).

Cytokine induction of MnSOD protein expression in MnSODsense and MnSODantisense insulin-producing RINm5F cells Both IL-1 $\beta$ and the cytokine mixture induced MnSOD protein expression irrespectively of the endogenous level of MnSOD expression in the different RINm5F cell clones (Fig. 3). The MnSOD protein expression level, induced by IL-1 $\beta(600 \mathrm{U} / \mathrm{ml})$ as well as by the cytokine mixture $(60 \mathrm{U} / \mathrm{ml}$ IL- $1 \beta, 185 \mathrm{U} / \mathrm{ml} \mathrm{TNF}-\alpha, 14$ $\mathrm{U} / \mathrm{ml}$ IFN- $\gamma$ ), was significantly higher in MnSODsense cells $(400 \%)$, and, albeit to a lesser extent, also in control cells $(220 \%)$ than in MnSODantisense cells (180\%) (Fig. 3).

\section{Discussion}

Insulin-producing cells are characterised by a particular imbalance of antioxidative defence between the two enzy- 
matic scavenger systems, namely the superoxide-radicaland the $\mathrm{H}_{2} \mathrm{O}_{2}$-inactivating enzyme systems. While the superoxide-radical-inactivating isoenzymes in the cytosol $(\mathrm{CuZnSOD})$ and in the mitochondria (MnSOD) are expressed at moderate but overall appropriate levels, the expression of the $\mathrm{H}_{2} \mathrm{O}_{2}$-inactivating enzymes catalase and GPx in insulin-producing cells is very low $[8,9]$. In situations of high superoxide radical production, as during the autoimmune attack of pancreatic beta cells in type 1 diabetes mellitus, this imbalance might result in a cytotoxic accumulation of $\mathrm{H}_{2} \mathrm{O}_{2}$.

Neither MnSOD overexpression nor MnSOD suppression had a significant effect on cell viability after incubation with $\mathrm{H}_{2} \mathrm{O}_{2}$. The toxicity of $\mathrm{HX} / \mathrm{XO}$, which releases $\mathrm{H}_{2} \mathrm{O}_{2}$ together with superoxide radicals extracellularly, was also not affected by changes in the MnSOD expression level in insulin-producing cells.

Reduced MnSOD gene expression in the MnSODantisense cells also left menadione toxicity unaltered. However, overexpression of MnSOD in the MnSODsense cells resulted in an enhanced toxicity. The toxicity of menadione is based on redox cycling with its semiquinone and the subsequent release of superoxide radicals [22, 23]. This redox process takes place preferentially in the mitochondria and explains the great toxicity of menadione to mitochondrial proteins and DNA [24].

These experiments allow the conclusion that an increased superoxide-radical-inactivation capacity in the MnSOD sense cells results in an enhanced $\mathrm{H}_{2} \mathrm{O}_{2}$ production, the inactivation of which is limited, however, by the low $\mathrm{H}_{2} \mathrm{O}_{2}$ detoxification capacity in insulin-producing cells [10, 25]. On the other hand, mitochondrial superoxide radical dismutation is apparently not rate-limiting in insulin-producing cells, since the viability was not reduced through MnSOD suppression in the MnSODantisense cells.

Overexpression of MnSOD also significantly enhanced the toxicity of IL-1 $\beta$ and a cytokine mixture consisting of IL- $1 \beta$, TNF- $\alpha$ and IFN- $\gamma$. Reduced MnSOD gene expression in MnSODantisense cells left the toxicity of IL-1 $\beta$ unaffected and in the case of the more toxic cytokine mixture it even provided protection. The greater toxicity of the cytokine mixture is apparently a result of TNF- $\alpha$-induced ROS formation in the mitochondria [10, 26-29]. The observed protective effect of a reduced MnSOD gene expression was evident not only in the MTT viability assay but also in the measurements of cell proliferation.

Thus, all experimental evidence provided in this study shows that an increased rate of dismutation of the superoxide radical to $\mathrm{H}_{2} \mathrm{O}_{2}$ in the mitochondria of insulin-producing cells through the antioxidant enzyme MnSOD fosters cytokine toxicity. The very low expression level of $\mathrm{H}_{2} \mathrm{O}_{2}$ inactivating enzymes in these cells $[8,9]$ prevents a fast and efficient removal of toxic $\mathrm{H}_{2} \mathrm{O}_{2}$ generated intramitochondrially through the action of MnSOD. Through overexpression of catalase within the mitochondrial compartment, we were able to protect insulin-producing cells against cytokine-induced toxicity and thus demonstrate the deleterious effects of mitochondrially accumulated $\mathrm{H}_{2} \mathrm{O}_{2}$ [10]. Enhanced toxicity due to increased MnSOD protein expression was also observed in MnSOD-overexpressing fibroblasts $[7,30,31]$, in skeletal muscle cells [32], in fibroblasts and in brain of patients suffering from neuronal ceroid lipofuscinosis type 6 [33], in the ovarian cancer cell line SK-OV-3 [34] and in transformed human bronchial epithelial cells [35].

An additional contributing/aggravating factor which explains the particularly pronounced toxicity of cytokines, is the ability of IL- $1 \beta$ to induce the expression of MnSOD protein in insulin-producing cells (Fig. 3) [36, 37] as well as in other cell types $[38,39]$ and the inhibition of catalase enzyme activity by $\mathrm{NO}[40]$, which fosters $\mathrm{H}_{2} \mathrm{O}_{2}$ generation. IL- $1 \beta$ is also known to decrease glutathione synthase expression in rat islets, and therefore additionally reduces antioxidative capacity of islets [41]. Through MnSOD suppression in MnSODantisense cells this additional toxic component of cytokine-induced toxicity is reduced but not abolished, since MnSOD induction in these cells reduces expression only to an expression level which is physiologically present in control cells not exposed to cytokines.

The results of the present experiments show that a complete chemical reduction of oxygen to $\mathrm{H}_{2} \mathrm{O}$ in the respiratory chain is crucial to prevent ROS-mediated toxicity in insulin-producing cells even though inactivation of superoxide radicals through SOD alone may ameliorate activation of signal cascades of cytokine-mediated cell death such as suppression of NF- $\mathrm{KB}$ activation [11]. Here it becomes evident that cytokine signalling comprises a complex chain of events, in which the generation of ROS seems to be a crucial event, although overexpression of MnSOD significantly reduced the initial activation of NF- $\mathrm{KB}$ [11] Thus the balance between the superoxide-radical- and $\mathrm{H}_{2} \mathrm{O}_{2}-$ inactivating enzyme systems is of particular importance in insulin-producing cells in order to prevent oxidative damage. This fact must also be kept in mind when devising therapeutic measures in order to strengthen resistance against the toxic actions of ROS and proinflammatory cytokines. A possible strategy for correction of this imbalance might be an increase of catalase activity in the mitochondrial compartment, thereby preventing the accumulation of $\mathrm{H}_{2} \mathrm{O}_{2}$ by elimination of this bottle-neck in the ROSinactivation chain [10]. This strategy may be combined with the overexpression of MnSOD to ensure a balanced elimination of mitochondrially generated radicals. Alternatively, a reduction of MnSOD activity by the antisense technique, as achieved in the present study, may adjust mitochondrial SOD activity to the existing low catalase and GPx expression preventing toxic effects of high levels of $\mathrm{H}_{2} \mathrm{O}_{2}$. Thus MnSOD represents a key target structure for antioxidative protection of beta cells whose benefit or harm crucially depend upon the expression level of $\mathrm{H}_{2} \mathrm{O}_{2}$ inactivating enzymes. 
Acknowledgements E. Gurgul-Convey was recipient of a grant from the DAAD (German Academic Exchange Service) on leave from the Faculty of Biotechnology, Jagiellonian University, Krakow, Poland. This study was supported in part by the Juvenile Diabetes Research Foundation International in the framework of the JDRF Centre for Prevention of Beta Cell Destruction in Europe. The authors are extremely grateful to Dr G. I. Bell (Department of Biochemistry and Molecular Biology, University of Chicago, Chicago, IL, USA) for the human MnSOD cDNA and Dr K. Asayama (Department of Pediatrics, School of Medicine, University of Occupational and Environmental Health, Iseigaoka, Kitakyushu, Japan) for the antibody against MnSOD.

\section{References}

1. Fridovich I (1995) Superoxide radical and superoxide dismutases. Annu Rev Biochem 64:97-112

2. Gardner R, Salvador A, Moradas-Ferreira P (2002) Why does SOD overexpression sometimes enhance, sometimes decrease, hydrogen peroxide production? A minimalist explanation. Free Radic Biol Med 32:1351-1357

3. Scott MD, Meshnick SR, Eaton JW (1989) Superoxide dismutase amplifies organismal sensitivity to ionizing radiation. J Biol Chem 264:2498-2501

4. Amstad P, Peskin A, Shah G et al (1991) The balance between $\mathrm{Cu}, \mathrm{Zn}$-superoxide dismutase and catalase affects the sensitivity of mouse epidermal cells to oxidative stress. Biochemistry 30 : 9305-9313

5. Kedziora J, Bartosz G (1988) Down's syndrome: a pathology involving the lack of balance of reactive oxygen species. Free Radic Biol Med 4:317-330

6. de Haan JB, Cristiano F, Iannello R, Bladier C, Kelner MJ, Kola I (1996) Elevation in the ratio of $\mathrm{Cu} / \mathrm{Zn}$-superoxide dismutase to glutathione peroxidase activity induces features of cellular senescence and this effect is mediated by hydrogen peroxide. Hum Mol Genet 5:283-292

7. Rodriguez AM, Carrico PM, Mazurkiewicz JE, Melendez JA (2000) Mitochondrial or cytosolic catalase reverses the MnSODdependent inhibition of proliferation by enhancing respiratory chain activity, net ATP production, and decreasing the steady state levels of $\mathrm{H}_{2} \mathrm{O}_{2}$. Free Radic Biol Med 29:801-813

8. Lenzen S, Drinkgern J, Tiedge M (1996) Low antioxidant enzyme gene expression in pancreatic islets compared with various other mouse tissues. Free Radic Biol Med 20:463-466

9. Tiedge M, Lortz S, Drinkgern J, Lenzen S (1997) Relation between antioxidant enzyme gene expression and antioxidative defense status of insulin-producing cells. Diabetes 46:1733-1742

10. Gurgul E, Lortz S, Tiedge M, Jörns A, Lenzen S (2004) Mitochondrial catalase overexpression protects insulin-producing cells against toxicity of reactive oxygen species and proinflammatory cytokines. Diabetes 53:2271-2280

11. Azevedo-Martins AK, Lortz S, Lenzen S, Curi R, Eizirik DL, Tiedge M (2003) Improvement of the mitochondrial antioxidant defense status prevents cytokine-induced nuclear factor-kappaB activation in insulin-producing cells. Diabetes 52:93-101

12. Forman HJB, Boveris A (1982) Superoxide radical and hydrogen peroxide in mitochondria. In: Pryor WA (ed) Free radicals in biology. Academic, New York, pp 65-90

13. Liochev SI, Fridovich I (1994) The role of $\mathrm{O}_{2}$ in the production of HO.: in vitro and in vivo. Free Radic Biol Med 16:29-33

14. Tiedge M, Lortz S, Munday R, Lenzen S (1998) Complementary action of antioxidant enzymes in the protection of bioengineered insulin-producing RINm5F cells against the toxicity of reactive oxygen species. Diabetes 47:1578-1585

15. Beck Y, Oren R, Amit B, Levanon A, Gorecki M, Hartman J (1987) Human Mn superoxide dismutase cDNA sequence. Nucleic Acids Res 15:9076

16. Fridovich I (1985) Xanthine oxidase. In: Greenwald RA (ed) Handbook of methods for oxygen radical research. CRC, Boca Raton, FL, pp 51-53
17. Trujillo M, Alvarez MN, Peluffo G, Freeman BA, Radi R (1998) Xanthine oxidase-mediated decomposition of $S$-nitrosothiols. J Biol Chem 273:7828-7834

18. Mosmann T (1983) Rapid colorimetric assay for cellular growth and survival: application to proliferation and cytotoxicity assays. J Immunol Methods 65:55-63

19. Lortz S, Tiedge M, Nachtwey T, Karlsen AE, Nerup J, Lenzen S (2000) Protection of insulin-producing RINm5F cells against cytokine-mediated toxicity through overexpression of antioxidant enzymes. Diabetes 49:1123-1130

20. Delaney CA, Pavlovic D, Hoorens A, Pipeleers DG, Eizirik DL (1997) Cytokines induce deoxyribonucleic acid strand breaks and apoptosis in human pancreatic islet cells. Endocrinology 138:2610-2614

21. Tiedge M, Lortz S, Munday R, Lenzen S (1999) Protection against the co-operative toxicity of nitric oxide and oxygen free radicals by overexpression of antioxidant enzymes in bioengineered insulin-producing RINm5F cells. Diabetologia 42:849855

22. Thor H, Smith MT, Hartzell P, Bellomo G, Jewell SA, Orrenius S (1982) The metabolism of menadione (2-methyl-1,4-naphthoquinone) by isolated hepatocytes. A study of the implications of oxidative stress in intact cells. J Biol Chem 257:12419-12425

23. Nakamura M, Hayashi T (1994) One- and two-electron reduction of quinones by rat liver subcellular fractions. J Biochem (Tokyo) 115:1141-1147

24. Druzhyna NM, Hollensworth SB, Kelley MR, Wilson GL, Ledoux SP (2003) Targeting human 8-oxoguanine glycosylase to mitochondria of oligodendrocytes protects against menadione-induced oxidative stress. Glia 42:370-378

25. Lortz S, Tiedge M (2003) Sequential inactivation of reactive oxygen species by combined overexpression of SOD isoforms and catalase in insulin-producing cells. Free Radic Biol Med 34:683-688

26. Goossens V, Grooten J, De Vos K, Fiers W (1995) Direct evidence for tumor necrosis factor-induced mitochondrial reactive oxygen intermediates and their involvement in cytotoxicity. Proc Natl Acad Sci U S A 92:8115-8119

27. Corda S, Laplace C, Vicaut E, Duranteau J (2001) Rapid reactive oxygen species production by mitochondria in endothelial cells exposed to tumor necrosis factor-alpha is mediated by ceramide. Am J Respir Cell Mol Biol 24:762-768

28. Meier B, Radeke HH, Selle S et al (1989) Human fibroblasts release reactive oxygen species in response to interleukin-1 or tumour necrosis factor-alpha. Biochem J 263:539-545

29. Schulze-Osthoff K, Beyaert R, Vandevoorde V, Haegeman G, Fiers W (1993) Depletion of the mitochondrial electron transport abrogates the cytotoxic and gene-inductive effects of TNF. EMBO J 12:3095-3104

30. Wenk J, Brenneisen P, Wlaschek M et al (1999) Stable overexpression of manganese superoxide dismutase in mitochondria identifies hydrogen peroxide as a major oxidant in the AP-1mediated induction of matrix-degrading metalloprotease-1. J Biol Chem 274:25869-25876

31. Ranganathan AC, Nelson KK, Rodriguez AM et al (2001) Manganese superoxide dismutase signals matrix metalloproteinase expression via $\mathrm{H}_{2} \mathrm{O}_{2}$-dependent ERK1/2 activation. J Biol Chem 276:14264-14270

32. McArdle A, van der Meulen J, Close GL et al (2004) Role of mitochondrial superoxide dismutase in contraction-induced generation of reactive oxygen species in skeletal muscle extracellular space. Am J Physiol Cell Physiol 286:C1152-C1158

33. Heine C, Tyynela J, Cooper JD et al (2003) Enhanced expression of manganese-dependent superoxide dismutase in human and sheep CLN6 tissues. Biochem J 376:369-376

34. Takada Y, Hachiya M, Park SH, Osawa Y, Ozawa T, Akashi M (2002) Role of reactive oxygen species in cells overexpressing manganese superoxide dismutase: mechanism for induction of radioresistance. Mol Cancer Res 1:137-146 
35. Kinnula VL, Pietarinen P, Aalto K, Virtanen I, Raivio KO (1995) Mitochondrial superoxide dismutase induction does not protect epithelial cells during oxidant exposure in vitro. Am J Physiol 268:L71-L77

36. Borg LA, Eizirik DL (1990) Short-term exposure of rat pancreatic islets to human interleukin-1 beta increases cellular uptake of calcium. Immunol Lett 26:253-258

37. Cardozo AK, Kruhoffer M, Leeman R, Orntoft T, Eizirik DL (2001) Identification of novel cytokine-induced genes in pancreatic beta-cells by high-density oligonucleotide arrays. Diabetes 50:909-920

38. Rogers RJ, Monnier JM, Nick HS (2001) Tumor necrosis factor-alpha selectively induces MnSOD expression via mitochondria-to-nucleus signaling, whereas interleukin-1beta utilizes an alternative pathway. J Biol Chem 276:20419-20427
39. Stephanz GB, Gwinner W, Cannon JK, Tisher CC, Nick HS (1996) Heat-aggregated IgG and interleukin-1-beta stimulate manganese superoxide dismutase in mesangial cells. Exp Nephrol 4:151-158

40. Sigfrid LA, Cunningham JM, Beeharry N et al (2003) Cytokines and nitric oxide inhibit the enzyme activity of catalase but not its protein or mRNA expression in insulin-producing cells. J Mol Endocrinol 31:509-518

41. Sparre T, Christensen UB, Mose Larsen P et al (2002) IL-1beta induced protein changes in diabetes prone $\mathrm{BB}$ rat Islets of Langerhans identified by proteome analysis. Diabetologia 45 : $1550-1561$ 